\title{
Integrating sustainability into construction project management: Barriers in developing countries
}

\author{
Ali Fathalizadeh ${ }^{1}$, Parviz Ghoddousi ${ }^{2}$, Ali Akbar Shirzadi Javid ${ }^{3}$, \\ M. Reza Hosseini ${ }^{4}$, Arka Ghosh ${ }^{5}$ \\ 1, 2, ${ }^{3}$ School of Civil Engineering, Iran University of Science and Technology, Narmak, Tehran, Iran \\ ${ }^{4,5}$ School of Architecture and built environment, Deakin University, Geelong, VIC, Australia
}

\section{E-mail:5ghoshar@deakin.edu.au (corresponding author)}

\begin{abstract}
This paper is an attempt to explore the barriers to integrating sustainability into construction project management in developing countries. To this end, a comprehensive review of the literature is conducted, as a result of which a list of 30 barriers is culled from existing studies. The list of barriers is subsequently assessed in terms of relative importance index (RII) through a survey questionnaire administered to Iranian construction industry experts, resulting in a dataset of 176 completed questionnaires. Findings bring to light the most influential barriers to incorporating sustainability in construction projects for a developing country. These were: (1) lack of understanding of the potential selfbenefits of proactivity and high economic risks that unsustainable practices may carry, (2) inadequate assessment of risks and a silo-based approach, namely, insufficient cooperation among practitioners, research institutions and environmental organisations and (3) the lack of a systematic approach to planning and acting for the fulfilment of sustainability goals. As one of the first studies in its kind, the paper offers invaluable insight for researchers, practitioners, and policy makers, in supporting the transition of construction project management practices towards fulfilling sustainable development goals.
\end{abstract}

Keywords: sustainable development, integration, construction projects, green building, challenges.

\section{Introduction}

There is an enormous demand for delivering construction projects in developing countries, as a result of their agenda for providing much needed infrastructure for advancing their economies. These effort, however, come at the expense of the environment (Banihashemi, Hosseini, Golizadeh, \& Sankaran, 2017; Hosseini et al., 2017). In order to achieve long-term economic gains along with preserving the built environment, there is an immediate need to move through sustainability in every field of business, including construction project management (Chawla, Chanda, \& Angra, 2018).

Integrating sustainability into various disciplines and practices has received considerable attention in recent years. A review of the literature, however, shows that very few studies have targeted construction project management. This presents a major problem, given that as announced By (International Energy Agency, 2018) in 2018, the construction industry is responsible for about $41 \%$ of total energy consumption globally, and close to $40 \%$ of total $\mathrm{CO}_{2}$ emissions. Despite these facts, integration of sustainability into construction project management practices has been very slow, with outcomes being far from satisfactory (Marcelino-Sádaba, González-Jaen, \& Pérez-Ezcurdia, 2015). This reflects the impacts of barriers, as a result of which, attempts towards making construction project management practices sustainable have been thwarted.

This study is the first attempt towards identifying these barriers. Findings will be invaluable for researchers through providing an illuminating insight into the nature of barriers, creating a stepping stone for future research on the topic. For practitioners, the list of barriers and the relative importance of each one assist practitioners and policy makers in allocating much needed resources to addressing the most influential barriers, hence enhancing their efficiency in overcoming barriers and challenges and identifying the areas in need of particular attention for making their practices sustainable. 


\section{Background and literature review}

There is consensus in the literature on the cardinal importance of considering sustainability in construction project management (Silvius, 2017; Sfakianaki, 2019). What follows next provides a background to the main themes and concepts associated with integrating sustainability into construction project management practices.

\section{Sustainability and the construction industry}

Sustainability is one of the most important challenges of contemporary businesses (Silvius, 2017), and the need for sustainable development has been widely documented (Redclift, 2005). In this regard, the scholarly literature demonstrates that the construction industry has a significant impact on the environment, as well as, on social and economic life, and it has become a growing concern (Sfakianaki, 2019). The revelation of data on to the impact of construction on the environment has attracted particular attention from politicians, administrative authorities, policy makers, construction professionals, the scientific community and consumers, worldwide (Kylili \& Fokaides, 2017; Sfakianaki, 2019). Sustainability concerns in delivering construction projects have been high on the agenda in advanced economies. Yet, developing countries have put economic development above meeting sustainability requirements. The need for economic growth in developing countries has fueled a huge demand for construction projects, hence environmental concerns being overshadowed (Banihashemi et al., 2017). Applying sustainability practices on construction project management has a wide range of dimensions based on various approaches, from the extraction of raw materials through the planning, design and construction of buildings and infrastructure, and their final deconstruction and management of the waste (Sfakianaki, 2019), a description of which follows.

\section{Integrating sustainability into construction project management}

Sustainability has been integrated into construction project management through various approaches in academic papers. Banihashemi et al. (2017) defines integrating sustainability into project management by providing a framework which encapsulates the identified success factors for delivery of construction projects. With the balanced requirement of environmental, economic and social aims in projects strengthening, the need for integrating sustainability into project management has drawn attention in both academia and practice. Especially for mega construction projects, how to accomplish sustainability-related objectives in project practices has been endowed with an invaluable importance (Yu, Zhu, Yang, Wang, \& Sun, 2018). Sánchez (2015) addresses this need to integrate sustainability into project management by evaluating the projects in case of their profits and economic, environmental and social impacts. Despite their broad potential and strong promotion within academic discourse, sustainable construction project management practices have not been widely adopted across the construction industry, mainly due to a plethora of barriers (Sánchez, 2015). These barriers in the construction context represent a real problem. According to Müller-Bloch and Kranz (2015), the term research problem - and the ensuing call for action/resolution - can also be applied interchangeably with the term research gap. This research problem - gap - acts as an input for conducting new studies. For the present study, it triggers further research with the aim of identification of such barriers, as discussed next.

\section{Barriers}

There are no studies in the field with specific attention to barriers to integration of sustainability into construction project management. Studies with the closest similarity with this aim are those that have addressed the topic from the perspective of critical success factors (CSF), affecting the integration of sustainability into construction project management (Banihashemi et al., 2017; Sfakianaki, 2019). Sfakianaki (2019) synthesizes and evaluates the available literature with respect to critical success factors (CSFs) for sustainable construction by reviewing the most pertinent papers from three publishers: Emerald, Elsevier and Wiley. Banihashemi et al. (2017) presented a list of CSFs and customizes it for the context of developing countries by conducting some interviews and presenting the outcome in the form of a conceptual model, where the model is afterwards validated through the data from 101 completed questionnaires with partial least squares structural equation modelling (PLS-SEM) as the method of analysis. This study strived to get an alternative perspective by focusing on barriers to the integration of sustainability into construction project management. Barriers have been extracted from the papers and reports addressing the issue of sustainability and presenting barriers or drivers to it. Some review articles are also available in this field of study (Silvius \& Schipper, 2014; Hakiminejad, Fu, \& Titkanlou, 2015; Marcelino-Sádaba et al., 2015; Ali, Boks, \& Bey, 2016; Thomé, Ceryno, Scavarda, \& Remmen, 2016; Aarseth, Ahola, Aaltonen, Økland, \& Andersen, 2017; Darko \& Chan, 2017; Medl, Stangl, \& Florineth, 2017; Nawaz \& Koç, 2018; Sfakianaki, 2019). However, most do not go beyond exploring the drivers and success factors for the integration of sustainability into construction project management (Sfakianaki, 2019; Banihashemi et al., 2017).

A list of 30 barriers to integrating sustainability into construction project management is tabulated in Table 1, as the outcome of conducting a comprehensive literature review. 
Fathalizadeh, A.; Ghoddousi, P.; Javid, A. A. S.; Reza Hosseini, M.; Ghosh, A. 2019.

Integrating sustainability into construction project management: Barriers in developing countries

Table 1. List of barriers ranked based on RII values

\begin{tabular}{|c|c|c|}
\hline Rank & Barrier & RII value \\
\hline 1 & $\begin{array}{l}\text { Lack of understanding of the potential self-benefits of proactivity and high economic risks that unsus- } \\
\text { tainable practices may carry }\end{array}$ & 0.8511 \\
\hline 2 & Insufficient cooperation between industries, academia and environmental organizations & 0.8443 \\
\hline 3 & Lack of a systematic approach to planning and acting for the fulfilment of sustainability & 0.8330 \\
\hline 4 & Lack of support from policy makers & 0.8307 \\
\hline 5 & Unstable economy & 0.8284 \\
\hline 6 & Lack of Organizational Support & 0.8148 \\
\hline 7 & Improved environmental or social sustainability is not valued in internal capital allocation decisions & 0.8080 \\
\hline 8 & Lack of sustainable practices in an organizations vision & 0.8011 \\
\hline 9 & Sociocultural constraints; like poor public awareness and demand & 0.7761 \\
\hline 10 & Corruption affecting the construction industry & 0.7716 \\
\hline 11 & Lack of proven return on investment & 0.7693 \\
\hline 12 & Lower priority for environmental or social equity issues & 0.7682 \\
\hline 13 & Project managers do not possess the required KSAs (knowledge, skill, ability) & 0.7670 \\
\hline 14 & Obstructive policies & 0.7568 \\
\hline 15 & Companies employment strategies which does not measure sustainability knowledge and abilities & 0.7545 \\
\hline 16 & Lack of data and transparency and information sharing between the construction firms and the suppliers & 0.7477 \\
\hline 17 & Absence of studies and education on sustainable delivery of construction projects & 0.7466 \\
\hline 18 & Political constraints and Inadequate legislation and legal enforcement by the government & 0.7432 \\
\hline 19 & Lack of stakeholders' early engagement & 0.7420 \\
\hline 20 & Difficulty in dealing with government agencies & 0.7364 \\
\hline 21 & Lack of investment & 0.7250 \\
\hline 22 & Poor market demand for green and recyclable construction materials & 0.7170 \\
\hline 23 & $\begin{array}{l}\text { Companies in developing countries change their unsustainable practices only if there is a proven return } \\
\text { on investment }\end{array}$ & 0.7159 \\
\hline 24 & Inadequate systems for managing information & 0.7136 \\
\hline 25 & $\begin{array}{l}\text { Lack of research addressing the issue and role of enablers in facilitating the successful implementation } \\
\text { of green procurement in local construction industries }\end{array}$ & 0.7045 \\
\hline 26 & Lack of formal education on sustainability & 0.6773 \\
\hline 27 & Slow innovation diffusion & 0.6773 \\
\hline 28 & Inadequate market supply of green products and services for comparison and selection of products & 0.6670 \\
\hline 29 & $\begin{array}{l}\text { Lack of an experienced and well-trained workforces with knowledge on sustainability practices in the } \\
\text { construction industry }\end{array}$ & 0.6614 \\
\hline 30 & Project management standards fail to address all sustainability aspects & 0.6330 \\
\hline 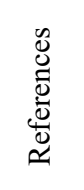 & \multicolumn{2}{|c|}{$\begin{array}{l}\text { (Elkhalifa, 2016; Chang, Soebarto, Zhao, \& Zillante, 2016; Gan, Zuo, Ye, Skitmore, \& Xiong, 2015; Banihashemi } \\
\text { et al., 2017; Hakiminejad et al., 2015; Wong, Chan, \& Wadu, 2016; Broman \& Robèrt, 2017; Tabassi, Ramli \& Ba- } \\
\text { kar, 2012; Ahsan, Ho \& Khan, 2013; UNDESA, 2013; Perera, Rameezdeen, Chileshe, \& Hosseini, 2014; Ojo, } \\
\text { Mbowa, \& Akinlabi, 2014; Varnäs, Balfors, \& Faith-Ell, 2009; Silvius \& Schipper, 2012; Aarseth et al., 2017; Local } \\
\text { Government Association of NVS, 2009) }\end{array}$} \\
\hline
\end{tabular}

\section{Methods}

As discussed, barriers were extracted through a comprehensive review of the literature, resulting in a list of 30 barriers. The barriers are examined through a survey returning 176 questionnaires from Iranian construction industry professionals, as a developing country. Subsequently, relative importance index (RII), as illustrated in Eq. (1) is used to rank the barriers and distinguish the most important ones, following the lessons by (Holt, 2014). 


$$
R I I=\frac{1_{n 1}+2_{n 2}+\ldots+A_{n A}}{A N},
$$

where: $n 1, n 2, \ldots n A$ - number of respondents scoring response stem integers 1 to $5 ; A$ - largest integer on the response scale; $N$ - number of respondent sample.

The $A$ is equal to 5 in this research and $N=176$.

\section{Findings}

Table 1 illustrates the results of ranking barriers based on the RII values calculated for each variable. RII values are showing the importance of each factor (Holt, 2014). Higher RII value proves that respondents have assigned a higher score to the specific variable.

Ranking the barriers based on their RII value indicates that "Lack of understanding of the potential self-benefits of proactivity and high economic risks that unsustainable practices may carry", "Insufficient cooperation between industries, academia and environmental organizations" and "Lack of a systematic approach to planning and acting for the fulfilment of sustainability" are the highest ranked barriers in this survey.

As illustrated in Table 1 "Inadequate market supply of green products and services for comparison and selection of products", "Lack of an experienced and well-trained workforces with knowledge on sustainability practices in the construction industry" and "Project management standards fail to address all sustainability aspects" are the lowest ranked barriers of integrating sustainability into construction projects' management in developing countries. This proves that construction professionals in Iran are expecting innovations like sustainability to be performed through an up-down approach rather than a bottom-up approach.

\section{Discussion and conclusion}

This study presents a review of the concepts involved with integrating sustainability into construction projects' management in developing countries. The review of literature listed 30 barriers which is subsequently assessed in terms of relative importance through a questionnaire survey administered to Iranian construction industry experts. This resulted in a dataset of 176 completed questionnaires. Based on the results of calculations, it is inferred that economic and regulatory barriers have a greater importance than items related to market and workforce awareness. To achieve societal changes at a scale and rate that are needed for sustainability to even be a possible outcome, Broman and Robèrt (2017) believe it is necessary to establish a thorough understanding, not the least among leaders, of the character, magnitude and urgency of the sustainability challenge as well as the self-benefit of competent proactivity for sustainability. Also a concrete methodological support for such proactivity is needed.

Today many leaders recognize climate change, shrinking biodiversity, poverty, erosion of trust, and several other problems. However, they typically do not know how the numerous problems are in fact symptoms rooted in a few overriding mechanisms of destruction of our ecological and social systems. It leads to missing opportunities and solutions that cause new and sometimes worse problems. Barriers like "insufficient cooperation between industries, academia and environmental organizations" and "lack of a systematic approach to planning and acting for the fulfilment of sustainability" follow suit hindering the penetration of sustainability in construction project management. There is a growing concern among industry recruiters in developing countries that students lack industry-relevant skills making them unemployable. On the other hand, students trust that getting a relevant degree assures them employability. This lack of systematic approach results in a major gap between academia and industry which lead to corporate entities recruiting employees with practical work experience whereas researchers do their studies in universities without considering workplace terms and issues. Besides these, environmental organizations in such countries are looked upon as obstructive organizations rather than supportive and value-adding ones.

Identifying the most influential barriers of sustainability offers invaluable insight for researchers, practitioners, and policy makers, in supporting the transition of project management practices towards fulfilling sustainability goals.

\section{References}

Aarseth, W., Ahola, T., Aaltonen, K., Økland, A., \& Andersen, B. (2017). Project sustainability strategies: A systematic literature review. International Journal of Project Management, 35(6), 1071-1083. https://doi.org/10.1016/j.ijproman.2016.11.006

Ahsan, K., Ho, M., \& Khan, S. (2013). Recruiting project managers: Signals from job advertisements competencies and recruitment a comparative analysis of. Project Management Journal, 44(5), 36-54. https://doi.org/10.1002/pmj.21366

Ali, F., Boks, C., \& Bey, N. (2016). Design for sustainability and project management literature - a review. Procedia CIRP, 48, 2833. https:/doi.org/10.1016/j.procir.2016.04.185

Banihashemi, S., Hosseini, M. R., Golizadeh, H., \& Sankaran, S. (2017). Critical success factors (CSFs) for integration of sustainability into construction project management practices in developing countries. International Journal of Project Management, 35(6), 1103-1119. https://doi.org/10.1016/j.ijproman.2017.01.014

Broman, G. I., \& Robèrt, K. H. (2017). A framework for strategic sustainable development. Journal of Cleaner Production, 140, 17-31. https://doi.org/10.1016/j.jclepro.2015.10.121 
Chang, R. D., Soebarto, V., Zhao, Z-y., \& Zillante, G. (2016). Facilitating the transition to sustainable construction: China's policies. Journal of Cleaner Production, 131, 534-544. https://doi.org/10.1016/j.jclepro.2016.04.147

Chawla, V. K., Chanda, A. K., \& Angra, S. (2018). The sustainable project management: A review and future possibilities V.K. Journal of Project Management, 3, 157-170. https://doi.org/10.5267/j.jpm.2018.2.001

Holt, D. G. (2014). Asking questions, analysing answers: relative importance revisited. Construction Innovation, 14(1), 2-16. https://doi.org/10.1108/CI-06-2012-0035

Darko, A., \& Chan, A. P. C. (2017). Review of barriers to green building adoption sustainable development. Sustainable Development, 25(3), 167-179. https://doi.org/10.1002/sd.1651

Elkhalifa, A. (2016). The magnitude of barriers facing the development of the construction and building materials industries in developing countries, with special reference to Sudan in Africa. Habitat International, 54, 189-198. https://doi.org/10.1016/j.habitatint.2015.11.023

Gan, X., Zuo, J., Ye, K., Skitmore, M., \& Xiong, B. (2015). Why sustainable construction? Why not? An owner's perspective. Habitat International, 47, 61-68. https://doi.org/10.1016/j.habitatint.2015.01.005

Hakiminejad, A., Fu, C., \& Titkanlou, H. M. (2015). A critical review of sustainable built environment development in Iran. Proceedings of the ICE-Engineering Sustainability, 168(3), 105-119. https://doi.org/10.1680/ensu.14.00017

Hosseini, M. R., Banihashemi, S., Rameezdeen, R., Golizadeh, H., Arashpour, M., \& Ma, L. (2017). Sustainability by information and communication technology: A paradigm shift for construction projects in Iran. Journal of Cleaner Production, 168, 1-13. https://doi.org/10.1016/j.jclepro.2017.08.200

International Energy Agency. (2018). World energy outlook 2018. Retrieved from https://www.iea.org/weo2018/

Kylili, A., \& Fokaides, P. A. (2017). Policy trends for the sustainability assessment of construction materials: a review. Sustainable Cities and Society, 35, 208-288. https://doi.org/10.1016/j.scs.2017.08.013

Marcelino-Sádaba, S., González-Jaen, L. F., \& Pérez-Ezcurdia, A. (2015). Using project management as a way to sustainability. from a comprehensive review to a framework definition. Journal of Cleaner Production, 99, 1-16. https://doi.org/10.1016/j.jclepro.2015.03.020

Medl, A., Stangl, R., \& Florineth, F. (2017). Vertical greening systems - A review on recent technologies and research advancement. Building and Environment, 125, 227-239. https://doi.org/10.1016/j.buildenv.2017.08.054

Müller-Bloch, C., \& Kranz, J. (2015). A framework for rigorously identifying research gaps in qualitative literature reviews. In Proceedings of International Conference on Information Systems (ICIS).

Nawaz, W., \& Koç, M. (2018). Development of a systematic framework for sustainability management of organizations. Journal of Cleaner Production, 171, 1255-1274. https://doi.org/10.1016/j.jclepro.2017.10.011

Ojo, E., Mbowa, C., \& Akinlabi, E. (2014). Barriers in implementing green supply chain management in construction industry. In Proceedings of the 2014 International Conference on Industrial Engineering and Operations Management (pp. 1974-1981). Retrieved from http://iieom.org/ieom2014/pdfs/432.pdf

Perera, B. A. K. S., Rameezdeen, R., Chileshe, N., \& Hosseini, M. R. (2014). Enhancing the effectiveness of risk management practices in Sri Lankan road construction projects: A Delphi approach. International Journal of Construction Management, 14(1), 1-14. https://doi.org/10.1080/15623599.2013.875271

Local Government Association of NVS. (2009). Sustainability learning guide: Barriers and drivers to sustainability. Sydney. Retrieved from https://www.lgnsw.org.au/files/imce-uploads/35/barriers-and-drivers-to-sustainability.pdf

Redclift, M. (2005). Sustainable development (1987-2005): An oxymoron comes of age. Sustainable Development, 13(4), $212-227$. https://doi.org/10.1002/sd.281

Sánchez, M. A. (2015). Integrating sustainability issues into project management. Journal of Cleaner Production, 96, 319-330. https://doi.org/10.1016/j.jclepro.2013.12.087

Sfakianaki, E. (2019). Critical success factors for sustainable construction: A literature review. Management of Environmental Quality: An International Journal, 30(1), 176-196. https://doi.org/10.1108/MEQ-02-2018-0043

Silvius, G. (2017). Sustainability as a new school of thought in project management. Journal of Cleaner Production, 166, 14791493. https://doi.org/10.1016/j.jclepro.2017.08.121

Silvius, A. J., \& Schipper, R. P. (2014). Sustainability in project management: A literature review and impact analysis. Social Business, 4(1), 63-96. https://doi.org/10.1362/204440814X13948909253866

Silvius, G., \& Schipper, R. (2012). Sustainability in project management. Gower.

Tabassi, A. A., Ramli, M., \& Bakar, A. H. A. (2012). Effects of training and motivation practices on teamwork improvement and task efficiency: The case of construction firms. International Journal of Project Management, 30(2), 213-224. https://doi.org/10.1016/j.ijproman.2011.05.009

Thomé, A. M. T., Ceryno, P. S., Scavarda, A., \& Remmen, A. (2016). Sustainable infrastructure: A review and a research agenda. Journal of Environmental Management, 184, 143-156. https://doi.org/10.1016/j.jenvman.2016.09.080

UNDESA. (2013). World economic and social survey 2013: Sustainable development challenges. United Nations, Department for Economic and Social Affairs.

Varnäs, A., Balfors, B., \& Faith-Ell, C. (2009). Environmental consideration in procurement of construction contracts: Current practice, problems and opportunities in green procurement in the Swedish construction industry. Journal of Cleaner Production, 17(13), 1214-1222. https://doi.org/10.1016/j.jclepro.2009.04.001

Wong, J. K. W., Chan, J. K. S., \& Wadu, M. J. (2016). Facilitating effective green procurement in construction projects: An empirical study of the enablers. Journal of Cleaner Production, 135, 859-871. https:/doi.org/10.1016/j.jclepro.2016.07.001

Yu, M., Zhu, F., Yang, X., Wang, L., \& Sun, X. (2018). Integrating sustainability into construction engineering projects: Perspective of sustainable project planning. Sustainability, 10(3), 784. https://doi.org/10.3390/su10030784 